\title{
The Effects of Ethical Leadership, Servant Leadership and Leader-Member Exchange on Compulsory Citizenship Behaviors
}

\author{
Harun Yildız \& Bora Yıldız \\ ${ }^{1}$ Turkish Air Force, Balıkesir, Turkey \\ ${ }^{2}$ Turkish Naval Academy, Istanbul, Turkey \\ Correspondence: Harun Yıldız, Turkish Air Force, Bandırma, Balıkesir, Turkey. Tel: 90-555-562-2806. E-mail: \\ dryildizharun@gmail.com
}

Received: November 27, 2015

Accepted: December 17, 2015

Online Published: January 25, 2016

doi: 10.5539/ibr.v9n2p19

URL: http://dx.doi.org/10.5539/ibr.v9n2p19

\begin{abstract}
In the last three decades, there are numerous studies have been done that investigate some extra role behaviors, their antecedents, and consequences. Although their beneficial effects are widely accepted, some recent studies indicate that extra role behaviors have not always voluntary nature i.e. compulsory citizenship behavior. Instead, the studies stress that sometimes extra-role behaviors are a product of pressure. Right at this point, compulsory citizenship behavior-the dark side of organizational citizenship behavior-appear in the management field. Despite the importance of this construct in terms of its potential negative effects, interestingly, there are limited researches in the literature. In this context, after a literature review on the concept of compulsory citizenship behavior, this study provides a theoretical framework on some rarely studied predictors i.e., ethical leadership, servant leadership, leader-member exchange. Managerial and further research implications are provided.
\end{abstract}

Keywords: compulsory citizenship behavior, ethical leadership, leader-member exchange, servant leadership

\section{Introduction}

Employee-related costs and losses take enormous part in the organizations' budgets. Correspondingly, there are plenty of studies that tried to uncover the way of minimizing the destructive effects of employee behaviors. Despite such behaviors, there are also studies that investigate the nature of extra-role behaviors, their antecedents, and consequences. Extra-role behaviors are defined as "behavior which benefits the organization and/or is intended to benefit the organization, which is discretionary and which goes beyond existing role expectations" (Vandyne et al., 1995). Although these behaviors refer a set of prosocial behaviors, they are used in the literature as if they are a uniform construct (Van Dyne \& LePine, 1998). Organizational citizenship behavior (OCB), employee voice, whistleblowing, prosocial organizational behaviors, organizational dissent, and helping behaviors are the types of extra-role behaviors (Van Dyne et al., 1995; Van Dyne \& LePine, 1998; Miles et al., 2002; Chiaburu et al., 2007). OCB, as a one of the extra-role behaviors, is defined as "individual behavior that is discretionary, not directly or explicitly recognized by the formal reward system, and in the aggregate promotes the efficient and effective functioning of the organization" (Organ, 1988). In the literature a great deal of studies has been conducted on the concept of OCB (Organ, 1988, 1990, 1997; Smith et al., 1983; Organ \& Ryan, 1995; Lepine et al., 2002; Peng \& Zhao, 2012; Podsakoff et al., 1990, 2009; Dalal, 2005; Walumbwa et al., 2010; Ziegler et al., 2012). Past studies show that some of the predictors of OCB are organizational justice (Niehoff \& Moorman, 1993; Farh et al., 1997; Moorman, 1991; Moorman et al., 1998; Podsakoff et al., 1990; Ehrhart, 2004; LePine et al., 2002; Netemeyer et al., 1997; Y1ldı, 2015), job satisfaction (Smith et al., 1983; Netemeyer et al., 1997), leadership styles (Alpkan et al., 2005), person-organization fit and perceived organizational support (Netemeyer et al., 1997). Chahahl and Mehta (2010) also emphasized that the effect of leadership style (Özşahin et al., 2011; Zehir et al., 2011; Ehrhart, 2004; Babcock-Roberson \& Strickland, 2010; Piccolo \& Colquitt, 2006; Deluga, 1995; Jiao et al., 2011; Kılıç et al., 2014), organizational commitment (Donaldson et al., 2000; Chen et al., 2002; Williams \& Anderson, 1991; Schappe, 1998; Zinabadi, 2010; Yumuşak et al., 2013), personality traits (Kamdar \& Van Dyne, 2007; Organ, 1994; Organ \& Lingl, 1995; Neuman \& Kickul, 1998), role clarity are also predictors of OCB. Given the prosocial nature of $\mathrm{OCB}$, its possible contributions to organizational performance are not surprising. To support this notion Chahal and Mehta (2010) describe five types of performance as consequences of OCB namely employee satisfaction, reduced absenteeism, reduced turnover intention and 
loyalty. As understood from these studies, in past three decades, past researchers comprehensively investigated antecedents and consequences of OCB. According to the literature, employee perceptions towards to their organizations have a critical role in emerging of OCB. Also, the majority of studies in the literature clearly indicate that if employees' perceptions are positive, they develop some positive attitudes and exhibit OCBs.

In addition to above-mentioned studies, recent research interest draws attention to voluntary nature of OCB (Bolino et al., 2004; 2010; Makishi, 2008; Peng \& Zhao, 2012; Vigoda-Gadot, 2006; 2007; Zhang et al., 2011). In other words, researchers claim that OCB sometimes emerge as a result of some kind of pressure (Alkan \& Turgut, 2015; Bolino et al., 2010; Vigoda-Gadot, 2006; 2007) and this type of OCB can be harmful for the organization even though it appears beneficial for organizations. Vigoda-Gadot $(2006 ; 2007)$ labeled this kind of OCB as "compulsory citizenship behavior (CCB)". Vigoda-Gadot (2007) defined CCB as "employees' engagement in extra-role, but not necessarily voluntary, behaviors that are conducted under duress and not as a result of the self-driven good will of the individual himself/herself'. As understood from this definition CCB emphasizes involuntary behaviors by comparison with the conventional OCB. Moreover, in contrast to conventional OCB, CCB can be accepted as a source of negative employee behaviors. For instance, Peng and Zhao (2012) state that CCB is negatively related to the contextual performance, organizational commitment. Zhao et al. (2013) also state that CCB is positively related to the abusive supervision and negatively related to psychological safety. Supporting these studies Zhao and Peng (2014) stress the importance of the organizational justice as predictors of CCB. Their findings show that, in their moderated mediation model, OCB has a negative impact on CCB, however, this relationship is not directly but through organizational identification when perceived interactional justice is low. As understood from these studies there are some studies with related to the CCB in the literature (see Table 1), however, given the importance of this construct CCB related studies are interestingly limited. In light of these explanations, in this paper, we highlighted the effects of employee's ethical leadership, servant leadership and leader-member exchange (LMX) perceptions on exhibiting compulsory citizenship behavior. Despite the importance of leaders as role models in the organizations, their role on the exhibiting compulsory citizenship behaviors has been interestingly underresearched. Therefore, the present study has three research questions: (a) is servant leadership a predictor of CCB? (b) is ethical leadership a predictor of $\mathrm{CCB}$, and (c) is the leader-member exchange (LMX) predictors of CCB?

The paper proceeds in the following manner. It begins with a literature review on compulsory citizenship behavior. Then the effects of ethical leadership, servant leadership and LMX on CCBs are discussed. Lastly, conclusion and implications are forwarded.

\section{Theoretical Frameworks and Propositions}

Social exchange theory (Blau, 1964) suggests that behaviors are the product of perceptions and attitudes. In other words, there is an exchange relationship among perceptions, attitudes and behaviors. In this respect, it is easy to say that according to social exchange explanations the pattern of behaviors is shaped by attitudes and perceptions. Supportively, Yildı et al. (2015a; 2015b) assert that positive perceptions trigger positive behaviors via positive attitudes or vice versa. On the other hand Yukl (2002) state that leaders have a power of influence on their followers. Past researchers indicate that role models influence prosocial behaviors (Mayer et al., 2010; Picollo et al., 2010) and destructive deviant workplace behaviors (Uddin et al., 2014; Van Gils et al., 2015). In light of these arguments, leaders, as role models, have an important role at fostering positive behaviors (Demirtas and Akdoğan, 2014; Demirtas, 2015) and preventing destructive or harmful employee behaviors. In the following section the effects of ethical leadership, servant leaderships, and LMX on compulsory citizenship behaviors are presented.

\subsection{Compulsory Citizenship Behavior}

Compulsory citizenship behaviors (CCBs) are defined as the dark side of organizational citizenship behaviors. Although Zhang et al. (2011) categorized OCBs into four types (see Figure 1) that based on voluntary levels of OCBs namely altruistic, responsible, reciprocity and compulsory OCBs, their approach is more holistic compared with to the other researchers. According to their literature review, instrumental and compulsory citizenship behaviors accepted as norms when environmental changes are prevalent. In other words, when uncertainty dominates the organizational environment these two kinds of OCB come to the forefront as a tool to avoid the ambiguity. As seen from Figure 1 CCB has negative effects on both individuals and organizations. 


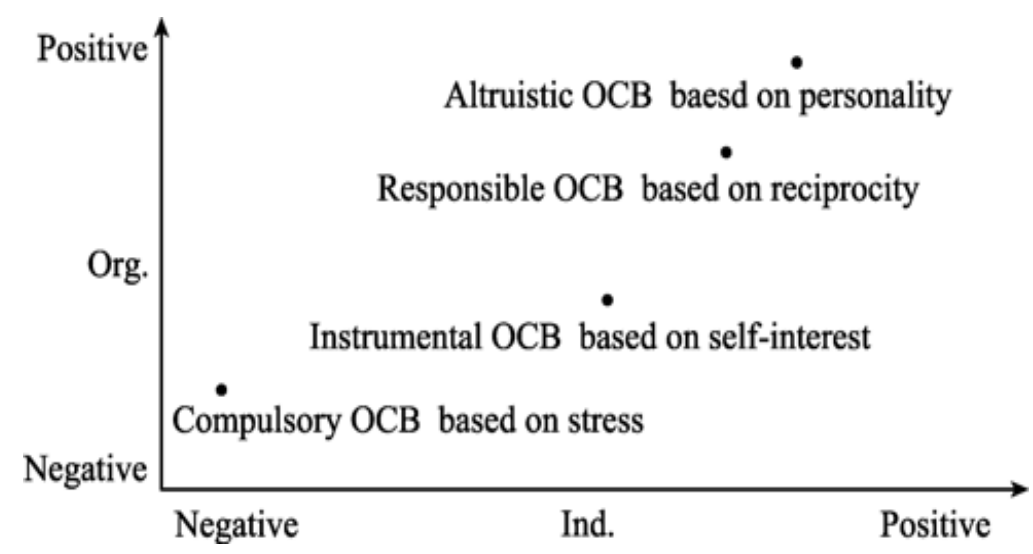

Figure 1. The consequence of OCB continuum for organization and employees (Zhang et al., 2011)

Conversely, the majority of the studies about CCB try to split this construct from the conventional OCB. Despite the submissive understanding of OCB, which is OCB is always beneficial for organizations was previously questioned by Bolino et al.'s (2004) study, there are limited researches have been done about the negative results of CCB up until now (see Table 1). Vigoda-Gadot' $(2006 ; 2007)$ frontier studies make an effort to construct and concept definition of CCB. In this respect, his studies have an important role in terms of understanding of this construct. In his concept definition, he draws attention to two important points about the CCB. Firstly, he states that if employees perceive pressure on themselves their OCBs are not as same as conventional OCB. As remembered Organ's a series of studies $(1988 ; 1990 ; 1997)$ conventional OCB has a voluntary nature and OCBs are the product of the "will". While conventional OCB stresses the will, CCB refers imposing OCB behaviors to employees. In other words, CCBs can be the result of some pressure sources such as themselves, family, manager, successful co-worker, and organizational climate (Alkan \& Turgut, 2015). Supporting this notion, Vigoda-Gadot (2006) stresses that employees are exposed to some kind of managerial and social pressures to exhibit non-task behaviors in the workplace. However, these behaviors lost their voluntary nature and beneficial effects contrary to what is believed (Vigoda-Gadot, 2006; 2007). Secondly, CCBs are seen as a kind of extra-role behaviors, however, the roots of these behaviors are not based on "self-driven will". Therefore, CCBs can be seen as an illusion in terms of being good citizenship.

Past researchers indicate that CCB is positively related to some negative outcomes and predictors. Although there are limited studies in the literature, these studies build consensus about the negative effects of $\mathrm{CCB}$ on employees and organizations. For instance, Vigoda-Gadot (2007), in their study, investigated the relationship between $\mathrm{CCB}$ and some negative constructs such as job stress, intention to leave, negligent behavior, and burnout. His findings show that CCB is positively related with these behaviors. Additionally, to stress negative side of $\mathrm{CCB}$, he also investigated the relationship between $\mathrm{CCB}$ and some positive constructs (i.e. innovation, job satisfaction, in-role performance, job autonomy participation decision making, and group level OCB). Similarly, his findings show that CCB is negatively related to all of these constructs except for the participation decision-making. On the other hand, Bolino et al. (2010) found that while citizenship pressure is a useful factor for boost OCBs, it is also positively related to some negative outcomes such as work-family conflict, job stress, work leisure conflict, and intention to quit. Zhao et al. (2014) also assert that CCB is negatively related to the OCB, interactional justice, and organizational identification. Peng and Zhao (2012) state that CCB is negatively related to contextual performance and organizational commitment. Zhao et al. (2013) also state that CCB is positively related to the abusive supervision and negatively related to psychological safety. As understood from the above-mentioned studies CCB is associated with the negative outcomes (see Table 1).

Given the limited studies in the literature, it has overlooked that employees' intention to exhibit CCBs may differ depending on their leadership perceptions. Since leaders have an influence on their followers and organizations (Gregory Stone et al., 2003), and since they affect extra role behaviors and organizational performance (Wang et al., 2005) they are important actors in organizations. When it is considered that leaders are followers-focused and ethical consideration-focused (i.e. servant leadership, ethical leadership) we suggest that these leaders are the source of positive behaviors and negative predictors of harmful behavior ie. CCBs. Also, we suggest that the quality of the relationship between leader and followers (LMX) is also positive predictors of prosocial or constructive organizational behaviors. Accordingly, we propose that if employees LMX quality is high, those employees may not prone to exhibit CCBs. 
Table 1. Compulsory citizenship behaviors related studies

\begin{tabular}{|c|c|c|c|}
\hline Source & Antecedents & Behavior & Consequences \\
\hline $\begin{array}{l}\text { Alkan (2015) } \\
\text { Alkan and Turgut (2015) }\end{array}$ & $\begin{array}{ll}\text { - } & \text { Organizational politics } \\
\text { - } & \text { Psychological safety } \\
\text { - } & \text { Pressure sources } \\
\end{array}$ & Compulsory Citizenship Behavior & - \\
\hline Bolino et al. (2010) & - Citizenship pressure & Compulsory Citizenship Behavior & $\begin{array}{l}\text { - Increased OCB } \\
\text { - Work-family conflict } \\
\text { - Work-leisure conflict } \\
\text { - Job stress } \\
\text { - Turnover intention } \\
\end{array}$ \\
\hline Zhao et al. (2014) & $\begin{array}{l}\text { - Compulsory citizenship behavior } \\
\text { - Interactional justice } \\
\text { - Organizational identification }\end{array}$ & Organizational Citizenship Behavior & - \\
\hline Zhao et al. (2013) & $\begin{array}{l}\text { - Psychological safety } \\
\text { - Abusive supervision } \\
\end{array}$ & Compulsory Citizenship Behavior & - \\
\hline Vigoda-Gadot (2006) & Concept definition & & \\
\hline Makishi (2008) & $\begin{array}{l}\text { - Gender } \\
\text { - Voluntary nature of OCB or CCB } \\
\text { - Type of behavior: altruistic or civic }\end{array}$ & $\begin{array}{l}\text { - Organizational Citizenship Behavior } \\
\text { - Compulsory Citizenship Behavior }\end{array}$ & - \\
\hline Peng and Zhao (2014) & $\begin{array}{l}\text { - Psychological contract violation } \\
\text { - Task performance } \\
\text { - Contextual performance } \\
\text { - Organizational commitment } \\
\text { - China tradition } \\
\end{array}$ & Compulsory Citizenship Behavior & - \\
\hline Vigoda-Gadot (2007) & $\begin{array}{l}\text { - Job stress } \\
\text { - Innovation } \\
\text { - Organizational politics } \\
\text { - Job satisfaction } \\
\text { - Turnover intention } \\
\text { - Negligent behavior } \\
\text { - Group-level OCB } \\
\text { - OCB } \\
\text { - Task performance } \\
\text { - Participation decision making } \\
\text { - Autonomy } \\
\text { - Status } \\
\text { - Education } \\
\text { - Tenure }\end{array}$ & Compulsory Citizenship Behavior & - \\
\hline Ylld $z$ and Ylld $\mathrm{lz}(2015 a)$ & A comparative approach to OCB and & (Literature review) & \\
\hline
\end{tabular}

\subsection{Ethical Leadership}

Ethical conduct and ethical dimension (moral) of the leadership become visible since prominent ethical scandals are seen in nearly every organizations such as business, government, and even religious organizations (Brown \& Trevino, 2006). Ethical leadership refers to "the actions, talks, and other behaviors which consist of appropriate norms" (Demirtas, 2015). According to Brown et al. (2005) ethical leadership is defined as "the demonstration of normatively appropriate conduct through personal actions and interpersonal relationships, and the promotion of such conduct to followers through two-way communication, reinforcement, and decision-making". Ethical leaders are defined as honest, caring, trustworthy, proactive and principled role models, who make fair and balanced decisions, communicate with their followers about ethics, and set clear ethical standards (Brown \& Trevino, 2006, p. 597; Mayer et al., 2009). Indeed, ethical leaders are perceived as fair since their approach to ethics based on justice insight (Shapiro \& Stefkovich, 2011). On the other hand, social learning theory (Bandura, 1977; 1986) is a theoretical basis for understanding ethical leadership because leaders affect the ethical actions of followers by means of modeling (Brown et al., 2005). Ethical leadership is an essential leadership behavior. Therefore, ethical leaders promote ethical behavior and initiate efforts to hinder unethical practices (Yukl, 2002). In line with this explanation, since ethical leaders are possible source of rewarding positive behaviors such as 
engaging in helping behaviors to assist colleagues, employees will be more prone to provide help to other employees when assistance is needed (Mayer et al., 2009). Thus, given the importance of ethical leadership, leaders need to better understanding of ethical issues (Shapiro \& Stefkovich, 2011). Especially, top managers should be ethical leader; otherwise the effects of ethical leadership will not spread in the organizations (Trevino et al., 2000).

There are many empirical studies in the literature that investigate the relationship between ethical leadership and its positive consequences. For example, Brown et al. (2005) found that ethical leadership was positively related to consideration behavior, honesty, trust in the leader, interactional fairness, socialized charismatic leadership, and abusive supervision. Also, they determined that ethical leadership is positively associated with outcomes such as perceived effectiveness of leaders, followers' job satisfaction and dedication (willing to give extra effort to one's job or contextual performance), and their willingness to report problems to management. Elci et al. (2012) state that ethical leadership and leadership effectiveness have a negative impact on turnover intention. Walumbwa and Schaubroeck (2009) found that the leader personality traits of agreeableness and conscientiousness were positively associated with ethical leadership. Additionally, they determined that followers' perceptions of psychological safety were partially mediated the relationship between ethical leadership and followers' voice behavior. Demirtas and Akdogan (2014) found that ethical leadership had both direct and indirect effects on affective commitment and turnover intention. Also, they determined that ethical leadership leads to greater affective organizational commitment and less turnover intention by shaping ethical climate. Results from Demirtas's (2015) study showed that ethical leadership has both direct and indirect effect on work engagement (positively) and organizational misbehavior (negatively). Mayer et al. (2009) found a negative relationship between both top management and supervisory ethical leadership and group-level deviance, and a positive relationship with group-level OCB. Also, they determined that supervisory ethical leadership mediated the effects of top management ethical leadership on group-level deviance and OCB. Brown and Trevino (2006, p. 596) proposed that ethical leadership is positively related to follower ethical decision-making, satisfaction, motivation and commitment and prosocial behavior, whereas it is negatively related to counterproductive behavior.

As a consequence of positive effects of ethical leadership, employees will have positive attitudes and behaviors toward their leaders. Since ethical leaders transmit high moral standards to employees, they encourage their followers to behave ethically in work-related processes and work context (Walumbwa \& Schaubroeck, 2009, p. 1276). Therefore, from social learning theory's view, while ethical leadership style will produce positive outcomes e.g. extra-role behaviors, it will decrease compulsory citizenship behaviors. Similarly, Blau's (1964) social exchange theory suggests that behaviors are the product of perceptions and attitudes. In light of these theoretical foundations, since employees' ethical leadership perceptions has an influence of their behaviors and since ethical leadership related studies prove the positive effect of it on employee behaviors we propose that ethical leadership is a one of the preventive predictors of CCB. In this context, it follows that:

Proposition 1: Ethical leadership is negatively related to the compulsory citizenship behaviors.

\subsection{Servant Leadership}

In consequence of changes in leadership theories, a new leadership style, which is introduced the term "servant leadership" emerged. Servant-leadership, firstly proposed by Robert K. Greenleaf in 1970, is an ethical perspective on leadership. Servant leaders serve others and satisfy their needs as a priority (Greenleaf, 1977; 1996; 2002). Servant-leaders are value-and character-driven people who are performance and process oriented (Page \& Wong, 2000). Greenleaf Center for Servant-Leadership (Smith, 2015, p. 4), defines servant leadership as "increased service to others; a holistic approach to work; promoting a sense of community; and the sharing of power in decision making." According to Page and Wong (2000), a servant leader is "a leader whose primary purpose for leading is to serve others by investing in their development and well-being for the benefit of accomplishing tasks and goals for the common good." Spears (1995) identified 10 major leadership characteristics based on Greenleaf's (1977) study: Calling, listening, empathy, healing, awareness, persuasion, conceptualization, foresight, stewardship, commitment to the growth of people, and community building. Then, Barbuto and Wheeler (2002) defined servant leadership with the 11 characteristics as adding calling characteristic-the natural desire to serve others.

This model of leadership emphasizes power sharing, fulfilling the needs of others first and focusing on the development of employees as far as possible (Greenleaf, 2015). Additionally, servant leadership leads to positive outcomes for organizations (individual and organizational). The positive impact of the servant leader affects employees to behave successfully and consequently contribute to their experience of positive emotions and 
successful behaviors (Dannhauser, 2007). Krekeler (2010) revealed that conscientiousness and agreeableness traits were positively associated with servant leadership. Hunter et al. (2013) found that leader agreeableness was positively related to servant leadership. Demirel et al. (2013) found strong and positive relationships between servant leadership and the quality of municipal services. Results from Rivkin et al.' (2014) study showed that servant leadership is positively related with employees' psychological health. Uru Sani et al. (2013) and Dal and Corbacioglu (2014) found a positive relationship between the servant leadership and the leader-member exchange. Barbuto and Wheeler (2002) also found that servant leadership is positively related with transformational leadership, leader-member exchange, motivation to perform extra effort, employee satisfaction, and organizational effectiveness. Washington (2007) found that employees' perceptions of their immediate supervisors' servant leadership were positively related to employees' job satisfaction and organizational commitment. Rimes (2011) found a positive relationship between the pastor's servant leadership style and members' affective and normative organizational commitment. Uru Sani et al. (2013) found that leader-member exchange and trust mediate the relationship between servant leadership and organizational citizenship behaviors and individual performance. Vondey (2010) found that servant leadership partially predicts organizational citizenship behaviors. In addition to this result, he determined that person-organization fit and organizational identification partially moderate the relationship between servant leadership behavior and organizational citizenship behavior. Barbuto and Wheeler (2002) proposed that servant leadership might affect other positive organizational outcomes, such as organizational citizenship behavior and other measures of performance. On the other hand, servant leadership affects negatively certain negative perceptions, emotions and behaviors. Orlan, and Di Natale-Svetnicka (2013) found that servant leadership negatively correlating with competitive and avoidance conflict management strategies, while positively correlates with collaborative, accommodating, and compromising conflict management strategies. Rivkin and colleagues' study showed that servant leadership is negatively related to emotional exhaustion and depersonalization (job strain). Also, they determined a negative relationship between servant leadership and ego depletion, and need for recovery (day-level indicators of strain). Han (2014) determined that as length of time working with the same supervisor increases, perceptions of employees' servant leadership decrease. Hunter et al. (2013) found that leader extraversion was negatively related to servant leadership. They found that servant leadership has a negative relationship with turnover intentions and disengagement. Additionally, they determined that service climate (at the group-level) mediated the effects of servant leadership on follower turnover intentions, helping and sales behavior.

Social learning theory (Bandura, 1977, 1986) has been used to explain the relationship of servant leadership with employees' attitudes and behaviors (Yıldız \& Y1ld1z, 2015b). Social learning theory accounts for why some individual characteristics of the leader and situational effects are related to followers' perceptions of a leader as a servant leader. According to social learning theory, individuals learn attitudes, values and behaviors by giving attention to them of which attractive and reliable models (Brown \& Treviño, 2006, p. 597). Given the servant leaders' interaction with the followers and positive and trust-based relations with the followers, it is easy to say that they give importance to the wellbeing of others and do not use any pressure toll as a performance booster method. Taking into account all of these explanations, since servant leaders have a positive influence on their followers, and since their followers perceive their leaders positively they will more prone to exhibit positive behaviors and avoid from harmful or undesired behaviors. It follows that:

Proposition 2: Servant leadership is negatively related to the compulsory citizenship behaviors.

\subsection{Leader-Member Exchange (LMX)}

The construct of leader-member exchange (LMX) was firstly investigated in 1972 (Zand, 1972; Schriesheim et al., 1999). The exchange process in LMX was used to describe higher-quality exchanges based on trust (Deluga, 1994, p. 318; Schriesheim et al., 1999, p. 76), i.e. conveying appropriate information, allowing mutuality of influence, promoting self-control and abstain from abuse of the vulnerability of others (Zand, 1972). In this respect, the mutually reinforcing of trust laid the foundations of social exchange in time (Brower et al., 2000; Whitener et al., 1998). LMX quality describes how effective leadership relationships improve between binary "partners" in and between organizations (e.g., leaders and followers, team members and teammates, employees and their competence networks, joint venture partners, suppliers networks, and so forth) (Graen \& Uhl-Bien, 1995). LMX is "(a) a system of components and their relationships (b) involving both members of a dyad (c) involving interdependent patterns of behavior and (d) sharing mutual outcome instrumentalities and (e) producing conceptions of environments, cause maps, and value (Scandura, Graen, \& Novak, 1986, p. 580)". LMX focuses on the benefits of high-quality individual relationships between leaders and followers (Hunt, 2014). According to Graen and Uhl-Bien (1995, p. 225), the development of LMX theory has four stages: "Is the discovery of differentiated dyads (Stage 1); is the investigation of characteristics of LMX relationships and their 
organizations implications (e.g., outcomes of LMX) (Stage 2); is the description of dyadic partnership building (Stage 3); and is the aggregation of differentiated dyadic relationships to group and network levels (Stage 4), respectively."

LMX theory proposes that leaders do not use the identical style in coping with all subordinates. Instead, they develop a different type of exchange with each subordinate (Liden \& Maslyn, 1998). The model of LMX in terms of the subordinate roles, and the quality of the LMX, is separated into two basic groups: The in-group and the out-group. The in-group is defined by high trust, interaction, support, formal/informal rewards, members' attitudes toward the job, the amount of time and energy invested in the job by subordinates and fewer job problems. The out-group relations are established strictly on the basis of official rules, policies, authority relations, and contracts, and hence the out-group is defined by low trust, interaction, support, and rewards (Dienesch \& Liden, 1986, pp. 621-622). Therefore, the quality of the relationship between leader and member is better than the out-group because the in-group relations are not only based on formal agreements and obligations in a contract (Uru Sani et al., 2013; Liden \& Maslyn, 1998). Consequently, in LMX theory, high-LMX leaders (at the time called "in-group"), develop trusting and reciprocal useful relationships with employees (e.g., respect, obligation), while servant leaders develop strong supportive relationships with other stakeholders (Graen \& Uhl-Bien, 1995; Greenleaf, 1996; Barbuto \& Wheeler, 2006). In this aspect, LMX is an important antecedent of managerial problem-solving effectiveness (Zand, 1972).

Social exchange theory (Blau, 1964) and the norm of reciprocity (Gouldner, 1960) have been used to explain the relationship of leader-member exchange with employees' attitudes and behaviors (Settoon et al., 1996). In the literature, a wide range of studies concerned with LMX has been conducted. Graen and Novak (1982) investigated the effects of leader-member exchange on productivity and satisfaction. In Scandura and Graen's work (1986) the initially low-LMX group showed significant contributions in productivity, job satisfaction, and supervisor satisfaction. Deluga (1994) found that LMX quality was positively associated with subordinates' organizational citizenship behaviors. Gerstner and Day's (1997) study indicated positive relationships between LMX and job performance, satisfaction with supervision, overall satisfaction, commitment, role clarity, and member competence. Settoon et al. (1996) found that leader-member exchange related to organizational citizenship and in-role behaviors. Wayne et al. (1997) found that leader linking and expectations of an employees and dyad tenure were positively related to LMX quality (antecedents). Besides, they determined that LMX was positively associated with performance and organizational citizenship behaviors (consequences). Wang et al. (2005) showed that leader-member exchange fully mediated the relationships between transformational leadership and task performance and organizational citizenship behaviors. Also, Barbuto and Wheeler (2002) found that leader-member exchange positively affects extra effort and employee satisfaction. On the other hand, LMX was associated with certain negative perceptions, emotions and behaviors in the literature. For example, Graen et al. (1982) found that LMK was negatively associated with employee turnover. Dulebohn et al. (2012) determined that negative affectivity and neuroticism are negatively related with LMX. Gerstner and Day's (1997) study showed negative relationships between LMX and role conflict and turnover intentions. Boies and Howell (2006) found that LMX was negatively related to team conflict.

As a result of exchange positive relationships both with organizations and immediate superiors, employees will have positive attitudes and behaviors toward leaders who trust to their employees and deal with them. While higher-quality exchanges on the basis of social exchange theory and the norm of reciprocity will produce positive outcomes, such as organizational citizenship behaviors, they will decrease compulsory citizenship behaviors. In this context, the following proposal was formulated:

Proposition 3: Leader-member exchange is negatively related to the compulsory citizenship behaviors.

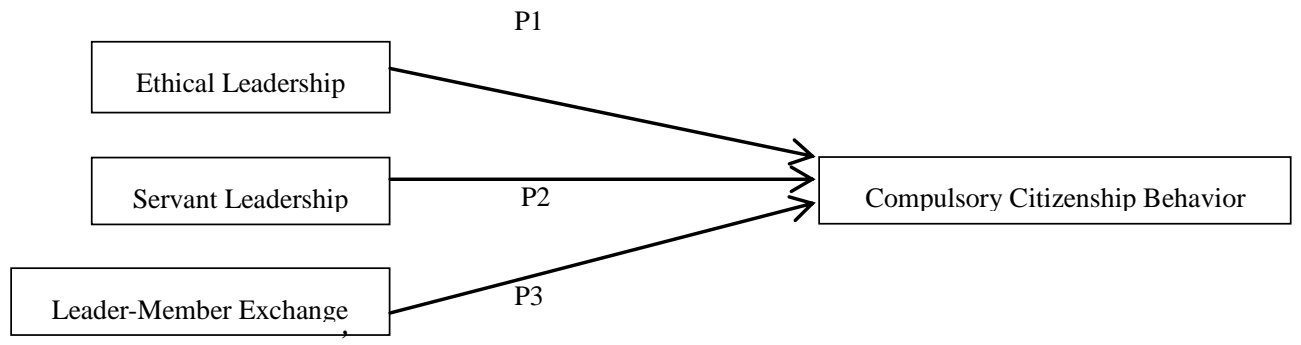

Figure 2. Theoretical model 


\section{Conclusion}

Leaders are important actors in organizations in terms of their effects on followers and organizations. Similarly, their relationship with the followers is one of the most important issues for organizations. Correspondingly, the quality of this relationship is also one of the key determinants of employee behaviors. In this paper, we developed a theoretical model, which was filtered from the current leadership and CCB literature. Based on existing literature, we noticed that the role of leadership styles and the quality of LMX in the emergence of CCBs have been overlooked. In this respect, to develop some theoretical propositions that draw attention to CCBs, Blau's (1964) social exchange theory shed light on our propositions. By highlighting the role of leaders and their relations with the followers, this study provides a theoretical model that might be useful for managers, practitioners, and academicians.

The present study begins with the defining the construct of CCBs and the relevant literature review. After defining ethical leadership, servant leadership, and LMX constructs their proposed effects on CCBs was formulated. In order to simplify proposed relations, proposed theoretical model was visualized in Figure 2. As a theoretical paper, the main aim of this study is to uncover the potential predictors of CCBs.

After the reviewing current literature, the present paper tried to give an answer to such research questions: (a) Is servant leadership a predictor of CCB? (b) Is ethical leadership a predictor of CCB, and (c) is leader-member exchange (LMX) predictors of CCB? Based on these research questions we try to close the gaps in the CCB's literature. Of course, this study is not established on the empirical logic, however, its proposed relations based on robust theoretical and empirical studies. To close these gaps, we firstly investigated the past researches, their findings and theoretical rationales, and then try to see the big picture of CCBs. The main motivation of this study began with the realizing the negative relationship between OCB and CCB (Vigoda-Gadot, 2007; Zhao et al., 2014). After the realizing this inverse relationship, we investigated that what factors are important for the emergence of OCBs. To do this, we investigated CCBs related studies and determined the studied predictors of it. After the determination of CCBs' predictors, we compared these predictors with the OCBs' predictors. This comparison show that CCBs related studies mostly focused on the pressure sources that accepted as root cause of CCBs (Bolino et al., 2010; Vigoda-Gadot, 2006, 2007; Alkan, 2015; Alkan \& Turgut, 2015; Zhang et al., 2011; Peng \& Zhao, 2012; Zhao et al., 2014; Zhao et al., 2013). In this respect, we focused on the factors that might be a source of pressure. Grojean et al. (2004) state that leaders have a power of influence on organizational climate. Therefore, we propose that some kind of leadership styles i.e. servant leadership, ethical leadership and their interaction with the followers may rasp or minimize the pressure on employees. In other words, these leadership styles focused on employees and give importance to intimate relations between leaders and their followers.

Blau's (1964) social exchange theory suggests that there is an exchange relationship among employee perceptions, attitudes, and behaviors. Briefly, this theory points that behaviors are a kind of response to their perceptions. In light of this theory, it is easy to say that if employee perceptions towards to their leaders are positive, they develop OCBs or other positive and constructive behaviors. Taking into account all of these indicators, we propose that negative perceptions of employees towards to their leaders may also be predictors of CCBs. Also, as stated previously, the quality of the relationship between leaders and followers is also an important factor for positive employee attitudes and behaviors (Hunt, 2014; Deluga, 1994; Gerstner \& Day, 1997; Settoon et al., 1996; Wayne et al., 1997; Wang et al., 2005). Therefore, we also propose that if the quality of LMX is high, employees may feel less pressure on themselves because of the trust-based relations (Deluga, 1994, p. 318; Brower et al., 2000; Whitener et al., 1998) and good level of empathy, in turn, they will more prone to OCBs than the CCBs.

By means of this study, we believe that it will be beneficial for practitioners, managers, and academicians who work in management field. Organizations may take actions to limit pressure on employees. To the extent that authoritarian leaders who see their power as a pressure tool to performance improving employees may realize that pressure is not always a useful instrument to increase outputs. In other words, employee focused leaders (i.e. servant leadership and ethical leadership) should be taken as a role model. Moreover, we also believe that by means of this study we draw leaders' attention to their relations with the followers and their pressure sources. By this means, we believe that time, cost, and competition related pressures would not conduct their human-driven approaches. Instead, organizations should provide an organizational milieu where OCB behaviors are the product of their good will. With this aim, leaders should not be output-focused; instead some positive attitudes such as organizational commitment and psychological ownership should be boosted. Moreover, positive employee perceptions towards to organizational climate, ethical climate, organizational culture etc. should be provided (Orucu \& Y1ld1z, 2012; Elci \& Alpkan, 2006; 2009; Y1ld1z \& Y1ld1z, 2015). In the directions of these explanations, further researches should investigate the some perceptions (e.g., ethical climate, organizational 
justice, organizational culture and organizational climate) on CCB behaviors. Additionally, further researches should also investigate the effects of other leadership styles on CCB behaviors e.g., authoritarian, authentic, transformational, transformational leadership etc. In addition to these future research directions, further researches also investigate some negative attitudes on the CCBs e.g. moral disengagement. Of course, there are also some possible negative outcomes of CCBs' such as low-level performance, deviant workplace behavior, and unethical behaviors. Further researchers should also investigate these possible negative outcomes.

Despite the strengths of this study, there are some limitations as well. Firstly, in this study, we investigated the effects of servant leadership, ethical leadership and LMX on the employees' CCBs theoretically. Therefore, investigating this model empirically will convey the purpose of this study one step beyond. Secondly, the other types of leadership were not discussed in this study, further researches should tackle all types of these behaviors partially or collectively to reach a holistic view about the effect of leadership on CCBs. Thirdly, in this study we investigated only leaders role on the emergence of CCBs. However, there are numerous organizational and individual level factors that may affect CCBs. In this respect, further researches should investigate the role of big five personality to uncover which personality traits are more prone to exhibit CCBs. Fourthly, the present paper focuses on the direct relationships. In order to reach more detailed information about the model and overcome the direct relationship blindness, further researches should investigate some perceptions and attitudes' mediator and moderator roles to discover tacit relations. Last but not least, as aforementioned above, despite the robust theoretical nature of it, it will fulfil its primary purpose when tested empirically by further researchers.

\section{References}

Alkan, S. E. (2015). A Research About The Relationship Of Psychological Safety and Organizational Politics Perception With Compulsory Citizenship Behavior. Unpublished Master Thesis, Marmara University.

Alkan, S. E., \& Turgut, T. (2015). A Research about the Relationship of Psychological Safety and Organizational Politics Perception with Compulsory Citizenship Behavior and the Pressures Behind Compulsory Citizenship Behavior. Research Journal of Business and Management, 2(2), 185-203. http://dx.doi.org/10.17261/Pressacademia.2015211506

Alpkan, L., Dilek, H., \& Bozloğan, R. (2005). Liderlik tarzlarının güven ve adalet algıSı yoluyla örgütsel bağlllık, iş tatmini ve örgütsel vatandaşlık davranışı üzerine etkileri. Savunma Bilimleri Dergisi, 4(1), 44-69.

Babcock-Roberson, M. E., \& Strickland, O. J. (2010). The relationship between charismatic leadership, work engagement, and organizational citizenship behaviors. The Journal of Psychology, 144(3), 313-326. http://dx.doi.org/10.1080/00223981003648336

Bandura, A. (1977). Social learning theory. Englewood, Cliffs, NJ: Prentice-Hall.

Bandura, A. (1986). Social foundations of thought and action. Englewood. Cliffs, NJ: Prentice-Hall.

Barbuto, J. E., \& Wheeler, D. W. (2006). Scale development and construct clarification of servant leadership. Group \& Organization Management, 31(3), 300-326. http://dx.doi.org/10.1177/1059601106287091

Blau, P. M. (1964). Exchange and power in social life. Transaction Publishers.

Boies, K., \& Howell, J. M. (2006). Leader-member exchange in teams: An examination of the interaction between relationship differentiation and mean LMX in explaining team-level outcomes. The Leadership Quarterly, 17(3), 246-257. http://dx.doi.org/10.1016/j.leaqua.2006.02.004

Bolino, M. C., Turnley, W. H., \& Niehoff, B. P. (2004). The other side of the story: Reexamining prevailing assumptions about organizational citizenship behavior. Human Resource Management Review, 14(2), 229-246. http://dx.doi.org/10.1080/00223981003648336

Bolino, M. C., Turnley, W. H., Gilstrap, J. B., \& Suazo, M. M. (2010). Citizenship under pressure: What's a "good soldier" to do? Journal of Organizational Behavior, 31(6), 835-855. http://dx.doi.org/10.1002/job.635

Brower, H. H., Schoorman, F. D., \& Tan, H. H. (2000). A model of relational leadership: The integration of trust and leader-member exchange. The Leadership Quarterly, 11(2), 227-250. http://dx.doi.org/10.1016/S1048-9843(00)00040-0

Brown, M. E., \& Treviño, L. K. (2006). Ethical leadership: A review and future directions. The Leadership Quarterly, 17(6), 595-616. http://dx.doi.org/10.1016/j.leaqua.2006.10.004

Brown, M. E., Treviño, L. K., \& Harrison, D. A. (2005). Ethical leadership: A social learning perspective for construct development and testing. Organizational Behavior and Human Decision Processes, 97(2), 
117-134. http://dx.doi.org/10.1016/j.obhdp.2005.03.002

Chahal, H., \& Mehta, S. (2010). Antecedents and consequences of organisational citizenship behavior (OCB): A conceptual framework in reference to health care sector. Journal of Services Research, 10(2), 25.

Chen, Z. X., Tsui, A. S., \& Farh, J. L. (2002). Loyalty to supervisor vs. organizational commitment: Relationships to employee performance in China. Journal of Occupational and Organizational Psychology, 75(3), 339-356. http://dx.doi.org/10.1348/096317902320369749

Chiaburu, D. S., Marinova, S. V., \& Lim, A. S. (2007). Helping and proactive extra-role behaviors: The influence of motives, goal orientation, and social context. Personality and Individual Differences, 43(8), 2282-2293. http://dx.doi.org/10.1016/j.paid.2007.07.007

Dal, L., \& Çorbacıoğlu, S. (2014). Hizmetkar liderlik davranışları ve lider-üye etkileşimci ilişkisi: Bir devlet üniversitesi üzerine araştırma. Süleyman Demirel Üniversitesi İktisadi ve İdari Bilimler Fakültesi Dergisi, 19(4), 287-310.

Dalal, R. S. (2005). A meta-analysis of the relationship between organizational citizenship behavior and counterproductive work behavior. Journal of Applied Psychology, 90(6), 1241-1255. http://dx.doi.org/10.1037/0021-9010.90.6.1241

Dannhauser, Z. (2007). Can the positive impact of servant leaders be associated with behaviors paralleling followers' $\quad$ success? Retrieved from https://www.regent.edu/acad/global/publications/sl_proceedings/2007/dannhauser.pdf

Deluga, R. J. (1994). Supervisor trust building, leader-member exchange and organizational citizenship behavior. Journal of Occupational and Organizational Psychology, 67(4), 315-326. http://dx.doi.org/10.1111/j.2044-8325.1994.tb00570.x

Deluga, R. J. (1995). The relationship between attributional charismatic leadership and organizational citizenship

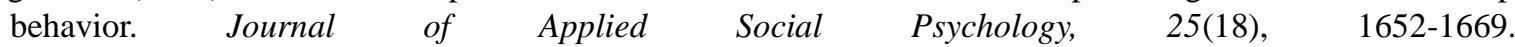
http://dx.doi.org/10.1111/j.1559-1816.1995.tb02638.x

Demirel, E. T., Yatkın, A., Düşükcan, M., Derin, N., Çakınberk, A., \& Güven, M. (2013). Vatandaşların belediye hizmet kalitesi algılamaları üzerinde belediye başkanlarının liderlik (hükümdar/hizmetkâr) özelliklerinin belirleyiciliği: TRB-I Bölgesi örneği. Çağdaş Yönetimler Dergisi, 22(2), 45-81.

Demirtas, O. (2015). Ethical leadership influence at organizations: Evidence from the field. Journal of Business Ethics, 126(2), 273-284. http://dx.doi.org/10.1007/s10551-013-1950-5

Demirtas, O., \& Akdogan, A. A. (2014). The effect of ethical leadership behavior on ethical climate, turnover intention, and affective commitment. Journal of Business Ethics, 130(1), 59-67. http://dx.doi.org/10.1007/s10551-014-2196-6

Dienesch, R. M., \& Liden, R. C. (1986). Leader-member exchange model of leadership: A critique and further development. Academy of management review, 11(3), 618-634. http://dx.doi.org/10.5465/AMJ.2005.17407908

Donaldson, S. I., Ensher, E. A., \& Grant-Vallone, E. J. (2000). Longitudinal examination of mentoring relationships on organizational commitment and citizenship behavior. Journal of Career Development, 26(4), 233-249. http://dx.doi.org/10.1023/A:1022947322349

Dulebohn, J. H., Bommer, W. H., Liden, R. C., Brouer, R. L., \& Ferris, G. R. (2012). A meta-analysis of antecedents and consequences of leader-member exchange integrating the past with an eye toward the future. Journal of Management, 38(6), 1715-1759. http://dx.doi.org/10.1177/0149206311415280

Ehrhart, M. G. (2004). Leadership and procedural justice climate as antecedents of unit-level organizational $\begin{array}{lllll}\text { citizenship behavior. } & \text { Personnel } & \text { Psychology, } & \text { 57(1), }\end{array}$ http://dx.doi.org/10.1111/j.1744-6570.2004.tb02484.x

Elçi, M., \& Alpkan, L. (2006). Etik iklimin örgütsel vatandaşlık davranışlarına etkileri. Hacettepe Üniversitesi İktisadi ve İdari Bilimler Fakültesi Dergisi, 4(1), 44-69.

Elçi, M., \& Alpkan, L. (2009). The impact of perceived organizational ethical climate on work satisfaction. Journal of Business Ethics, 84(3), 297-311. http://dx.doi.org/10.1007/s10551-008-9709-0

Elçi, M., Sener, İ, Aksoy, S., \& Alpkan, L. et al. (2012). The Impact of Ethical Leadership and Leadership Effectiveness on Employees' Turnover Intention: The Mediating Role of Work Related Stress, 8th 
International Strategic Management Conference, Procedia-Social and Behavioral Sciences, 58, $289-297$.

Farh, J. L., Earley, P. C., \& Lin, S. C. (1997). Impetus for action: A cultural analysis of justice and organizational citizenship behavior in Chinese society. Administrative Science Quarterly, 421-444. http://dx.doi.org/10.2307/2393733

Gerstner, C. R., \& Day, D. V. (1997). Meta-analytic review of leader-member exchange theory: Correlates and construct issues. Journal of Applied Psychology, 82(6), 827. http://dx.doi.org/10.1037/0021-9010.82.6.827

Gouldner, A. W. (1960). The norm of reciprocity: A preliminary statement. American Sociological Review, 25(2), 161-178.

Graen, G. B., \& Uhl-Bien, M. (1995). Relationship-based approach to leadership: Development of leader-member exchange (LMX) theory of leadership over 25 years: Applying a multi-level multi-domain perspective. The Leadership Quarterly, 6(2), 219-247. http://dx.doi.org/10.1016/1048-9843(95)90036-5

Graen, G. B., Liden, R. C., \& Hoel, W. (1982). Role of leadership in the employee withdrawal process. Journal of Applied Psychology, 67(6), 868-872. http://dx.doi.org/10.1037/0021-9010.67.6.868

Graen, G., Novak, M. A., \& Sommerkamp, P. (1982). The effects of leader-member exchange and job design on productivity and satisfaction: Testing a dual attachment model. Organizational Behavior and Human Performance, 30(1), 109-131. http://dx.doi.org/10.1016/0030-5073(82)90236-7

Greenleaf, R. K. (1970). The servant as a leader. Indianapolis, IN: Greenleaf Center.

Greenleaf, R. K. (1996). On becoming a servant leader. San Francisco: Jossey-Bass.

Greenleaf, R. K. (2015). What is servant leadership? Retrieved from https://greenleaf.org/what-is-servant-leadership/

Greenleaf, R. K. (1977). Servant leadership: A journey into the nature of legitimate power and greatness. New York, Paulist Press.

Greenleaf, R. K. (2002). Servant leadership: A journey into the legitimate power and greatness. 25th Anniversary Edition, New York, Paulist Press.

Gregory, S. A., Russell, R. F., \& Patterson, K. (2004). Transformational versus servant leadership: A difference in leader focus. Leadership \& Organization Development Journal, 25(4), $349-361$. http://dx.doi.org/10.1108/01437730410538671

Grojean, M. W., Resick, C. J., Dickson, M. W., \& Smith, D. B. (2004). Leaders, values, and organizational climate: Examining leadership strategies for establishing an organizational climate regarding ethics. Journal of Business Ethics, 55(3), 223-241. http://dx.doi.org/10.1007/s10551-004-1275-5

Han, R. (2014). Hotel employees' perceptions of supervisors' servant leadership behaviors, and relationships with employees' affective commitment (Unpublished master thesis). Iowa State University, USA.

Hunt, T. J. (2014). Leader-member exchange relationships in health information management. Perspectives in Health Information Management, 1-8.

Hunter, E. M., Neubert, M. J., Perry, S. J., Witt, L. A., Penney, L. M., \& Weinberger, E. (2013). Servant leaders inspire servant follower: Antecedents and outcomes for employees and the organization. The Leadership Quarterly, 24(2), 316-331. http://dx.doi.org/10.1016/j.leaqua.2012.12.001

Jiao, C., Richards, D. A., \& Zhang, K. (2011). Leadership and organizational citizenship behavior: OCB-specific meanings as mediators. Journal of Business and Psychology, 26(1), 11-25. http://dx.doi.org/10.1007/s10869-010-9168-3

Kamdar, D., \& Van Dyne, L. (2007). The joint effects of personality and workplace social exchange relationships in predicting task performance and citizenship performance. Journal of applied psychology, 92(5), 1286-1298. http://dx.doi.org/10.1037/0021-9010.92.5.1286

Kılıç, R., Keklik, B., \& Yıldız, H. (2014). Dönüştürücü, Etkileşimci ve Tam Serbesti Tanıyan Liderlik Tarzlarının Örgütsel Sessizlik Üzerindeki Etkisini Belirlemeye Yönelik Bir Araştırma. Yönetim ve Ekonomi: Celal Bayar Üniversitesi İktisadi ve İdari Bilimler Fakültesi Dergisi, 21(2), 249-268. http://dx.doi.org/10.18657/yecbu.48089

Krekeler, L. A. (2010). The relationship between servant leadership behavior and individual personality style in New York annual conference united methodist pastors (Unpublished master thesis). Seton Hall University, USA. 
LePine, J. A., Erez, A., \& Johnson, D. E. (2002). The nature and dimensionality of organizational citizenship behavior: A critical review and meta-analysis. Journal of Applied Psychology, 87(1), 52-65. http://dx.doi.org/10.1037/0021-9010.87.1.52

Liden, R. C., \& Maslyn, J. M. (1998). Multidimensionafity of leader-member exchange: An empirical assessment through scale development. Journal of Management, 24(1), 43-72. http://dx.doi.org/10.1177/014920639802400105

Makishi, N. (2008). Same Behavior, Different Consequences: Reasctions To Men's and Women's Compulsory Citizenship Behaviors (Unpublished Master Thesis). Utica College of Syracuse University.

Mayer, D. M., Kuenzi, M., Greenbaum, R., Bardes, M., \& Salvador, R. B. (2009). How low does ethical leadership flow? Test of a trickle-down model. Organizational Behavior and Human Decision Processes, 108(1), 1-13. http://dx.doi.org/10.1016/j.obhdp.2008.04.002

Mayer, D., Kuenzi, M., \& Greenbaum, R. (2010). Examining the link between ethical leadership and employee misconduct: The mediating role of ethical climate. Journal of Business Ethics, 95, 7-16. http://dx.doi.org/10.1007/s10551-011-0794-0

Miles, D. E., Borman, W. E., Spector, P. E., \& Fox, S. (2002). Building an integrative model of extra role work behaviors: A comparison of counterproductive work behavior with organizational citizenship behavior. International Journal of Selection and Assessment, 10(1/2), 51-57. http://dx.doi.org/10.1111/1468-2389.00193

Moorman, R. H. (1991). Relationship between organizational justice and organizational citizenship behaviors: Do fairness perceptions influence employee citizenship? Journal of Applied Psychology, 76(6), 845. http://dx.doi.org/10.1037/0021-9010.76.6.845

Moorman, R. H., Blakely, G. L., \& Niehoff, B. P. (1998). Does perceived organizational support mediate the relationship between procedural justice and organizational citizenship behavior? Academy of Management journal, 4l(3), 351-357. http://dx.doi.org/10.2307/256913

Netemeyer, R. G., Boles, J. S., McKee, D. O., \& Mc Murrian, R. (1997). An investigation into the antecedents of organizational citizenship behaviors in a personal selling context. The Journal of Marketing, 85-98. http://dx.doi.org/10.2307/1251791

Neuman, G. A., \& Kickul, J. R. (1998). Organizational citizenship behaviors: Achievement orientation and $\begin{array}{llll}\text { personality. Journal of Business and Psychology, 13(2), 263-279. } & \text {. }\end{array}$ http://dx.doi.org/10.1023/A:1022963108025

Niehoff, B. P., \& Moorman, R. H. (1993). Justice as a mediator of the relationship between methods of monitoring and organizational citizenship behavior. Academy of Management Journal, 36(3), 527-556. http://dx.doi.org/10.2307/256591

Organ, D. W. (1988). Organizational citizenship behavior: The good soldier syndrome. Lexington Books/DC Heath and Com.

Organ, D. W. (1990). The motivational basis of organizational citizenship behavior. Research in Organizational Behavior, 12(1), 43-72.

Organ, D. W. (1994). Personality and organizational citizenship behavior. Journal of Management, 20(2), 465-478. http://dx.doi.org/10.1177/014920639402000208

Organ, D. W. (1997). Organizational citizenship behavior: It's construct clean-up time. Human Performance, 10(2), 85-97. http://dx.doi.org/10.1207/s15327043hup1002_2

Organ, D. W., \& Lingl, A. (1995). Personality, satisfaction, and organizational citizenship behavior. The journal of Social Psychology, 135(3), 339-350. http://dx.doi.org/10.1080/00224545.1995.9713963

Organ, D. W., \& Ryan, K. (1995). A meta-analytic review of attitudinal and dispositional predictors of $\begin{array}{llll}\text { organizational citizenship behavior. Personnel Psychology, 48(4), } & \text { 775-802. }\end{array}$ http://dx.doi.org/10.1111/j.1744-6570.1995.tb01781.x

Orlan, K. S. C., \& DiNatale-Svetnicka, A. V. (2013). Relationships between servant leadership and conflict management style. Retrieved from https://kristaclementsorlan.wordpress.com/2013/07/22/relationships-between-servant-leadership-and-confli ct-management-style 
Örücü, E., \& Yıldız, H. (2012). Örgütsel kültür boyutlarının belirlenmesine yönelik bir araştırma: Bir telekomünikasyon şirketi örneği. Uludağ Üniversitesi İktisadi ve İdari Bilimler Fakültesi Dergisi, 31(2), 129-154.

Özsahin, M., Zehir, C., \& Acar, A. Z. (2011). Linking leadership style to firm performance: The mediating effect of the learning orientation. Procedia-Social and Behavioral Sciences, 24, 1546-1559. http://dx.doi.org/10.1016/j.sbspro.2011.09.089

Page, D., \& Wong, T. P. (2000). A conceptual framework for measuring servant leadership. In Adjibolossoo (Ed.), The human factor shaping the course of history and development. Lanham, American University Press.

Peng, Z. L., \& Zhao, H. D. (2012). Does organization citizenship behavior really benefit the organization? Study on the compulsory citizenship behavior in China. Nankai Business Review International, 3(1), 75-92. http://dx.doi.org/10.1108/20408741211201935

Piccolo, R. F., \& Colquitt, J. A. (2006). Transformational leadership and job behaviors: The mediating role of core job characteristics. Academy of Management Journal, 49(2), 327-340. http://dx.doi.org/10.5465/AMJ.2006.20786079

Piccolo, R. F., Greenbaum, R., Den Hartog, D. N., \& Folger, R. (2010). The relationship between ethical leadership and core job characteristics. Journal of Organizational Behavior, 31(2-3), 259-278. http://dx.doi.org/10.1002/job.627

Podsakoff, N. P., Whiting, S. W., Podsakoff, P. M., \& Blume, B. D. (2009). Individual-and organizational-level consequences of organizational citizenship behaviors: A meta-analysis. Journal of Applied Psychology, 94(1), 122. http://dx.doi.org/10.1037/a0013079

Podsakoff, P. M., MacKenzie, S. B., Moorman, R. H., \& Fetter, R. (1990). Transformational leader behaviors and their effects on followers' trust in leader, satisfaction, and organizational citizenship behaviors. The Leadership Quarterly, 1(2), 107-142. http://dx.doi.org/10.1016/1048-9843(90)90009-7

Rimes, W. D. (2011). The relationship between servant leadership and organizational commitment (Unpublished Doctoral Thesis). Tennessee Temple University, USA.

Rivkin, W., Diestel, S., \& Schmidt, K. H. (2014). The positive relationship between servant leadership and employees' psychological health: A multi-method approach. Zeitschrift für Personalforschung, 28(1-2), 52-72. http://dx.doi.org/1010.1688/ZfP-2014-01-Rivkin

Scandura, T. A., \& Graen, G. B. (1984). Moderating effects of initial leader-member exchange status on the effects of a leadership intervention. Journal of Applied Psychology, 69(3), 428-436. http://dx.doi.org/10.1037/0021-9010.69.3.428

Scandura, T. A., Graen, G. B., \& Novak, M. A. (1986). When managers decide not to decide autocratically: An investigation of leader-member exchange and decision influence. Journal of Applied Psychology, 71(4), 579. http://dx.doi.org/10.1037/0021-9010.71.4.579

Schappe, S. P. (1998). The influence of job satisfaction, organizational commitment, and fairness perceptions on organizational citizenship behavior. The Journal of Psychology, 132(3), 277-290. http://dx.doi.org/10.1688/zfp-2014-01-rivkin

Schriesheim, C. A., Castro, S. L., \& Cogliser, C. C. (1999). Leader-member exchange (LMX) research: A comprehensive review of theory, measurement, and data-analytic practices. The Leadership Quarterly, 10(1), 63-113. http://dx.doi.org/10.1016/S1048-9843(99)80009-5

Settoon, R. P., Bennett, N., \& Liden, R. C. (1996). Social exchange in organizations: Perceived organizational support, leader-member exchange, and employee reciprocity. Journal of Applied Psychology, 81(3), 219. http://dx.doi.org/10.1037/0021-9010.81.3.219

Shapiro, J. P., \& Stefkovich, J. A. (2011). Ethical leadership and decision making in education: Applying theoretical perspectives to complex dilemmas (3rd ed.). New York, NY: Routledge.

Smith, C. (2015). Servant Leadership: The Leadership Theory of Robert K. Greenleaf. Retrieved from http://www.carolsmith.us/downloads/640greenleaf.pdf

Smith, C. A., Organ, D. W., \& Near, J. P. (1983). Organizational citizenship behavior: Its nature and antecedents. Journal of Applied Psychology, 68(4), 653-663. http://dx.doi.org/10.1111/j.1744-6570.2006.00043_9.x

Spears, L. C. (1995). Reflections on leadership: How Robert K. Greenleaf's theory of servant-leadership 
influenced today's top management thinkers. New York: John Wiley.

Trevino, L. K., Hartman, L. P., \& Brown, M. (2000). Moral person and moral manager: How executives develop a reputation for ethical leadership. California Management Review, 42(4), 128-142.

Uddin, M. A., Rahman, M. S., \& Howlader, M. H. R. (2014). Exploring the relationships among transformational leadership, deviant workplace behavior, and job performance: An empirical study. $A B A C$ Journal, 34(1), 1-12.

Ürü Sanı, O., Çalişkan, S. C., Atan, Ö., \& Yozgat, U. (2013). Öğretim üyelerinin hizmetkâr liderlik davranışları ve ardıllari üzerine bir araştırma. Ege Academic Review, 13(1), 63-82.

Van Dyne, L., \& LePine, J. A. (1998). Helping and voice extra-role behaviors: Evidence of construct and predictive validity. Academy of Management Journal, 41(1), 108-119. http://dx.doi.org/10.2307/256902

Van Gils, S., Van Quaquebeke, N., Van Knippenberg, D., Van Dijke, M., \& De Cremer, D. (2015). Ethical leadership and follower organizational deviance: The moderating role of follower moral attentiveness. The Leadership Quarterly, 26(2), 190-203. http://dx.doi.org/10.1016/j.leaqua.2014.08.005

Vandyne, L., Cummings, L. L., \& Parks, J. M. (1995). Extra-role behaviors-in pursuit of construct and definitional clarity (a bridge over muddied waters). Research in Organizational Behavior: An Annual Series of Analytical Essays and Critical Reviews, 17, 215-285.

Vigoda-Gadot, E. (2007). Redrawing the boundaries of OCB? An empirical examination of compulsory extra-role behavior in the workplace. Journal of Business and Psychology, 21(3), 377-405. http://dx.doi.org/10.1007/s10869-006-9034-5

Vigoda-Gadot, E. R. A. N. (2006). Compulsory citizenship behavior: Theorizing some dark sides of the good soldier syndrome in organizations. Journal for the Theory of Social Behavior, 36(1), 77-93. http://dx.doi.org/10.1111/j.1468-5914.2006.00297.x

Vondey, M. (2010). The relationships among servant leadership, organizational citizenship behavior, person-organization fit, and organizational identification. International Journal of Leadership Studies, 6(1), 3-27.

Walumbwa, F. O., \& Schaubroeck, J. (2009). Leader personality traits and employee voice behavior: Mediating roles of ethical leadership and work group psychological safety. Journal of Applied Psychology, 94(5), 1275. http://dx.doi.org/10.1037/a0015848

Walumbwa, F. O., Hartnell, C. A., \& Oke, A. (2010). Servant leadership, procedural justice climate, service climate, employee attitudes, and organizational citizenship behavior: A cross-level investigation. Journal of Applied Psychology, 95(3), 517. http://dx.doi.org/10.1037/a0018867

Wang, H., Law, K. S., Hackett, R. D., Wang, D., \& Chen, Z. X. (2005). Leader-member exchange as a mediator of the relationship between transformational leadership and followers' performance and organizational citizenship behavior. Academy of Management Journal, 48(3), 420-432. http://dx.doi.org/10.5465/AMJ.2005.17407908

Washington, R. R. (2007). Empirical relationships among servant, transformational, and transactional leadership: similarities, differences, and correlations with job satisfaction and organizational commitment (Unpublished Doctoral Thesis). Auburn University, USA.

Wayne, S. J., Shore, L. M., \& Liden, R. C. (1997). Perceived organizational support and leader-member exchange: A social exchange perspective. Academy of Management journal, 40(1), 82-111. http://dx.doi.org/10.2307/257021

Whitener, E. M., Brodt, S. E., Korsgaard, M. A., \& Werner, J. M. (1998). Managers as initiators of trust: An exchange relationship framework for understanding managerial trustworthy behavior. Academy of Management Review, 23(3), 513-530. http://dx.doi.org/10.5465/AMR.1998.92662

Williams, L. J., \& Anderson, S. E. (1991). Job satisfaction and organizational commitment as predictors of organizational citizenship and in-role behaviors. Journal of Management, 17(3), 601-617. http://dx.doi.org/10.1177/014920639101700305

Yıldız, B., \& Yıldız, H. (2015a). Örgütsel vatandaşlıktan zorunlu vatandaşlığa: Karşılaştırmalı bir yaklaşıim. Saarbrücken, Germany: OmniScriptum GmbH \& Co. KG, Türkiye Alim Kitapları.

Yıldız, B., \& Yıldız, H. (2015b). The Effect of Servant Leadership on Psychological Ownership: The Moderator 
Role of Perceived Organizational Support. Journal of Global Strategic Management, 9(2), In press.

Yıldız, H. (2015). Positive piskolojik sermaye, örgütsel güven ve örgütsel vatandaşlık davranışı arasındaki ilişki: Bir alan araştırması (Unpublished Doctoral Thesis). Balıkesir University, Turkey.

Yıldız, B., Alpkan, L., Ateş, H., \& Sezen, B. (2015a). Determinants of Constructive Deviance: The Mediator Role of Psychological Ownership. International Business Research, 8(4), 107-121. http://dx.doi.org/10.5539/ibr.v8n4p107

Yıldız, B., Erat. S., Alpkan, L., Yıldız, H., \& Sezen, B. (2015b). Drivers of Innovative Constructive Deviance: A Moderated Mediation Analysis. Procedia-Social and Behavioral Sciences, 195, 1407-1416.

Yukl, G. A. (2002). Leadership in organizations (5th ed.). Englewood Cliffs, NJ: Prentice Hall.

Yumuşak, S., Özafşarlıŏlu, S., \& Yıldız, H. (2013). İş Tatmini İle Örgütsel Bağlılık Arasındaki İlişkinin İncelenmesi: Uşak Tekstil Sektöründe Bir Uygulama. Ege Stratejik Araştırmalar Dergisi, 4(2), 56-79.

Zand, D. (1972). Trust and managerial problem solving. Administrative Science Quarterly, 17(2), 229-239. http://dx.doi.org/10.2307/2393957

Zehir, C., Ertosun, Ö. G., Zehir, S., \& Müceldili, B. (2011). The effects of leadership styles and organizational culture over firm performance: Multi-National companies in İstanbul. Procedia-Social and Behavioral Sciences, 24, 1460-1474. http://dx.doi.org/10.1016/j.sbspro.2011.09.032

Zeinabadi, H. (2010). Job satisfaction and organizational commitment as antecedents of Organizational Citizenship Behavior (OCB) of teachers. Procedia-Social and Behavioral Sciences, 5, 998-1003. http://dx.doi.org/10.1016/j.sbspro.2010.07.225

Zhang, Y., Liao, J., \& Zhao, J. (2011). Research on the organizational citizenship behavior continuum and its consequences. Frontiers of Business Research in China, 5(3), 364-379. http://dx.doi.org/10.1007/s11782-011-0135-2

Zhao, H., Peng, Z., Han, Y., Sheard, G., \& Hudson, A. (2013). Psychological mechanism linking abusive supervision and compulsory citizenship behavior: A moderated mediation study. The Journal of Psychology, 147(2), 177-195. http://dx.doi.org/10.1080/00223980.2012.680522

Zhao, H., Peng, Z., \& Chen, H. K. (2014). Compulsory citizenship behavior and organizational citizenship behavior: the role of organizational identification and perceived interactional justice. The Journal of Psychology, 148(2), 177-196. http://dx.doi.org/10.1080/00223980.2013.768591

Ziegler, R., Schlett, C., Casel, K., \& Diehl, M. (2012). The role of job satisfaction, job ambivalence, and emotions at work in predicting organizational citizenship behavior. Journal of Personnel Psychology. 11(4), 176-190. http://dx.doi.org/10.1027/1866-5888/a000071

\section{Copyrights}

Copyright for this article is retained by the author(s), with first publication rights granted to the journal.

This is an open-access article distributed under the terms and conditions of the Creative Commons Attribution license (http://creativecommons.org/licenses/by/3.0/). 